\title{
PERBEDAAN PASTA GIGI HERBAL DAN NON-HERBAL TERHADAP PENURUNAN PLAQUE INDEX SCORE PADA ANAK
}

\author{
Ambar Puspitasari*, Merlya Balbeid**, Abdurrahman Adirhesa*** \\ *Departemen IKGA Fakultas Kedokteran Gigi Universitas Brawijaya Malang \\ **Departemen IKGMP Fakultas Kedokteran Gigi Universitas Brawijaya Malang \\ ***Program Studi Pendidikan Dokter Gigi Universitas Brawijaya Malang \\ Korespondensi: Ambar Puspitasari, E-mail: ambarpuspitasari04@gmail.com
}

\begin{abstract}
ABSTRAK
Salah satu bahan yang terkandung dalam pasta gigi adalah daun sirih. Fenol dan turunannya dalam minyak atsiri daun sirih dapat mengubah sifat protein sel bakteri dan menghambat pertumbuhan plak. Tujuan: Untuk mengetahui perbedaan penggunaan antara pasta gigi herbal dan pasta gigi non- herbal terhadap penurunan skor plak pada anak sekolah dasar. Metode: Jenis penelitian ini adalah true eksperimental dengan pre- and post-test control grup design. Responden dilakukan pemeriksaan skor plak kemudian diberikan penyuluhan tentang cara sikat gigi menggunakan teknik roll. Responden dibagi menjadi dua kelompok. Kelompok A diinstruksikan menyikat gigi menggunakan pasta gigi non-herbal dan kelompok B menggunakan pasta gigi herbal selama 14 hari dan dilakukan pemeriksaan skor plak kembali. Hasil: Hasil uji statistik T-berpasangan dalam setiap kelompok perlakuan menunjukkan terdapat perbedaan yang signifikan $(p<0,05)$ sebelum dan setelah menyikat gigi menggunakan pasta gigi herbal dan pasta gigi non herbal. Nilai rata-rata penurunan akumulasi plak lebih besar pada kelompok pasta gigi herbal. Kesimpulan: Pasta gigi yang mengandung herbal daun sirih lebih menurunkan skor plak gigi dari pada pasta gigi nonherbal.
\end{abstract}

Kata Kunci: plak, pasta gigi herbal, pasta gigi non-herbal, daun sirih 


\title{
DIFFERENCE OF HERBAL AND NON-HERBAL TOOTHPASTE TOWARDS DECREASING PLAQUE INDEX SCORE ON CHILDREN
}

\begin{abstract}
One of the substance contained in toothpaste is piper betle leaves. Fenol and its derivative in atsiri oil of piper betle leaves could change the protein characteristic of bacteria and inhibit growth of dental plaque. Purpose: to determine the differencess of herbal and non-herbal's toothpaste on decreasing plaque score to the elementary children. Method: this experiment was true experimental with pre and pos- test control group design. Respondens was examined plaque score and given counseling on how to brushing teeth using roll technique. The respondens were divided into two groups. Group $A$ was instructed brushing teeth using non-herbal toothpaste and group B using herbal toothpaste for 14 days and then continued with the examination the plaque score again. Results: Independent paired T-test in each group showed that there was significant difference $(p<0,05)$ before and after brushing using herbal toothpaste and non-herbal toothpaste. The mean reduction of plaque accumulation was greater on the group with herbal toothpaste. Conclusion: Toothpaste with herbal substances (piper betle leaves) reduce more dental plaque score than nonherbal toothpaste.
\end{abstract}

Keywords: plaque, herbal toothpaste, non-herbal tooth paste, piper betle leaves

\section{A. Pendahuluan}

Kesehatan merupakan faktor yang sangat penting dalam kelangsungan hidup manusia, begitu juga dengan kesehatan gigi dan mulut. Penyakit gigi dan mulut yang paling banyak ditemukan di masyarakat luas yaitu karies gigi. ${ }^{1}$ Karies tidak hanya terjadi pada orang dewasa, remaja namun dapat juga terjadi pada anak-anak. Karies disebabkan oleh banyak hal, salah satu faktor yang menyebabkan terjadinya karies adalah adanya plak yang tertimbun pada sela-sela gigi. Proses dari pembentukan plak gigi terlihat lebih cepat pada anak usia 8-12 tahun dari pada orang dewasa. ${ }^{2}$

Plak gigi merupakan bakteri biofilm yang terbentuk pada permukaan gigi yang terdiri atas mikroorganisme yang berkembang biak dalam suatu matriks interseluler, jika seseorang melalaikan kebersihan gigi dan mulutnya. Timbulnya plak gigi dapat dicegah dengan cara melakukan tindakan preventif 
yaitu dengan cara melakukan sikat gigi yang disertai dengan penggunaan pasta gigi. Di pasaran terdapat berbagai produk pasta gigi dengan berbagai macam merk dengan komposisi yang bermacam macam. Diantaranya adalah pasta gigi dengan bahan yang mengandung herbal dan pasta gigi yang tidak mengandung herbal. ${ }^{3}$

Pasta gigi adalah bahan pembantu yang digunakan untuk membersihkan gigi secara mekanis dari sisa makanan, menghilangkan plak, dan bau tak sedap pada mulut. Pasta gigi dibuat dengan tujuan untuk membantu menjaga kesehatan rongga mulut. ${ }^{4}$

Pasta gigi yang beredar di pasaran mengandung komposisi yang berfungsi untuk menjaga kesehatan gigi. Ada berbagai macam bahan yang terkandung dalam pasta gigi nonherbal seperti bahan abrasif, air, bahan terapeutik dan masih banyak lagi. Bahan bahan tersebut menjadi suatu komposisi yang menjadi satu sehingga dapat digunakan sebagai sarana membantu menjaga kebersihan rongga mulut. ${ }^{5}$

Pasta gigi herbal lebih unggul dibandingkan pasta gigi konvensional dalam pengurangan plak. Penambahan herbal pada pasta gigi dapat menghambat pertumbuhan plak, karena beberapa jenis herbal memiliki kemampuan menghambat pertumbuhan mikroba. Bahan antimikroba pada ekstrak daun sirih berperan sebagai bahan aktif dan mampu membunuh bakteri yang menjadi penyebab terbentuknya plak. Selain itu, karena herbal berasal dari tumbuh-tumbuhan, maka bahan tersebut aman dan alami. ${ }^{6}$

Berdasarkan latar belakang di atas, maka peneliti ingin mengetahui perbedaan penggunaan pasta gigi herbal dengan pasta gigi non-herbal terhadap skor plak pada anak sekolah dasar.

\section{METODE}

Jenis penelitian ini menggunakan metode true eksperimental design pre- and post-test control grup design, yaitu dengan melakukan pengukuran sebelum dan sesudah diberikan perlakuan. sampel dalam penelitian ini adalah siswa kelas 3A, 4A dan 5A di SDN 2 Dinoyo Malang. Sampel diambil dengan teknik simple random sampling. Besar sampel yang digunakan sebanyak 42 siswa dan memenuhi kriteria inklusi dan eksklusi. Kriteria inklusinya antara lain siswa Sekolah Dasar Negri 2 Dinoyo Malang, berusia 8-12 tahun, dan mendapat persetujuan orang tua. Kriteria eksklusinya adalah siswa yang sedang dalam perawatan ortodontik.

Penelitian ini dilakukan di SDN 2 Dinoyo Malang. Alat dan bahan yang disiapkan meliputi kaca mulut, pinset, sonde, excavator, pasta gigi herbal, pasta gigi non-herbal, masker, handscone, tip applicator, cotton pellet, disclossing agent, alat sterilisasi (Alkohol 90\%), buku saku dan alat tulis.

\section{Tahap penelitian awal (pre-test)}

Responden diberi penyuluhan menggunakan video animasi tentang 
pentingnya menjaga kebersihan gigi dan mulut dan cara menyikat gigi menggunakan teknik Roll. Setelah penyuluhan, dilakukan pengukuran skor plak indeks responden. Gigi diulasi dengan disclosing agent menggunakan tip applicator pada rahang atas permukaan labial bukal palatal dan rahang bawah labial bukal lingual.

Pemeriksaan skor plak menggunakan metode PHPM (Metode Personal Performance Modified) dengan cara membagi permukaan gigi yang diperiksa menjadi 5 bagian yaitu mesial, distal, sepertiga gingival dari area tengah, sepertiga tengah dari area tengah, dan sepertiga insisal dari area tengah kemudian dilakukan pemeriksaan pada gigi paling posterior yang tumbuh di kwadran kanan atas, gigi kaninus atas kanan sulung atau permanen bila gigi ini tidak ada dapat digunakan gigi anterior lainnya, gigi molar satu atas kiri sulung atau premolar satu atas kiri, gigi paling posterior yang tumbuh di kwadran kiri bawah, gigi kaninus kiri bawah sulung atau permanen bila gigi ini tidak ada dapat dipakai gigi anterior lainnya, gigi molar satu kanan bawah sulung atau premolar satu kanan bawah. Setelah diulasi disclossing agent, responden diminta berkumur dengan air kemudian dilakukan pencatatan skor plak pada borang nilai.

\section{Tahap penelitian kedua (post test):}

Responden dibagi menjadi dua kelompok yaitu kelompok A sebanyak 21 siswa untuk perlakuan terhadap pasta gigi non- herbal dan kelompok B sebanyak 21 siswa untuk pasta gigi herbal. Kedua kelompok diinstruksikan untuk menyikat gigi menggunakan teknik Roll sebanyak 2 kali sehari dalam waktu 14 hari yaitu pagi hari setelah sarapan dan malam hari sebelum tidur. Tiap responden kemudian diberi buku saku. Orangtua diikutsertakan mengontrol kegiatan sikat gigi yang dilakukan oleh anak di rumah dan diminta untuk menandatangi buku saku yang diberikan kepada seluruh responden setiap kali responden selesai melakukan sikat gigi.

Pada hari ke-15, semua responden di lakukan perhitungan skor plak setelah diberikan perlakuan menggunakan pasta gigi non-herbal dan pasta gigi herbal dan dilakukan pencatatan pada borang penilaian. Data yang diperoleh kemudian dianalisa menggunakan uji T berpasangan.

\section{HASIL PENELITIAN}

Hasil pemeriksaan skor plak dengan menggunakan PHPM (Metode Personal Performane Modified) dapat dilihat pada tabel 1.

Tabel 1. Rata-rata skor plak sebelum dan sesudah diberikan perlakuan menggunakan pasta gigi non-herbal dan herbal.

\begin{tabular}{|l|l|l|}
\hline Skor Plak & \multicolumn{3}{|l|}{ Rata-rata } \\
\cline { 2 - 3 } & $\begin{array}{l}\text { Pasta Gigi } \\
\text { Non-Herbal }\end{array}$ & $\begin{array}{l}\text { Pasta Gigi } \\
\text { Herbal }\end{array}$ \\
\hline
\end{tabular}




\begin{tabular}{|l|l|l|}
\hline $\begin{array}{l}\text { Sebelum } \\
\text { diberi } \\
\text { perlakuan }\end{array}$ & 34,57 & 33,67 \\
\hline $\begin{array}{l}\text { Setelah } \\
\text { diberi } \\
\text { perlakuan }\end{array}$ & 18,24 & 13,05 \\
\hline Penurunan & 16,33 & 20,62 \\
\hline
\end{tabular}

Penurunan indeks plak pada sampel penggunaan pasta gigi non-herbal dan pasta gigi herbal diuji dengan menggunakan uji T berpasangan. Hasil penurunan skor plak pada penggunaan kedua pasta gigi yaitu 0,000 $(p<0,05)$, sehingga dapat dikatakan terjadi penurunan indeks plak yang signifikan pada penggunaan pasta gigi herbal dan pasta gigi non-herbal. Penurunan skor plak lebih banyak pada pasta gigi herbal dibandingkan pada pasta gigi non-herbal.

\section{PEMBAHASAN}

Penyikatan gigi dengan menggunakan pasta gigi herbal dapat menurunkan skor plak lebih banyak dari pada pasta gigi non-herbal. Penurunan ini terjadi karena pasta gigi herbal memiliki kelebihan dalam kandungan ekstrak daun sirihnya yaitu minyak atsiri. ${ }^{5}$ Minyak atsiri merupakan komponen fenol alami yang dapat berfungsi sebagai antiseptik yang kuat. Kinerja dari fenol memiliki efek sebagai antibakteri terhadap beberapa jenis bakteri dan salah satunya merupakan bakteri yang sering berada di dalam rongga mulut yaitu streptococcus mutans. Adanya fenol yang berupa senyawa toksik mampu mengakibatkan struktur dari protein terganggu dan terbuka sehingga menjadi struktur yang acak. Hal ini menyebabkan kandungan protein terdenaturasi dan aktivitas biologis menjadi rusak sehingga mempengaruhi pertumbuhan dari bakteri streptococcus menjadi terhenti. Senyawa ini bersifat bakterisidal dan menghambat proses glikolisasi oleh bakteri kariogenik penghasil glukan yang dapat mengurangi pembentukan plak gigi. $^{7}$

Kandungan lain yang terdapat dalam minyak atsiri seperti kavikol, eugenol, kavibetol, tannin dan saponin yang mengandung zat antiseptik dan anti jamur. ${ }^{8}$ Kandungan senyawa saponin yang mempunyai sifat sebagai bahan surfaktan yang kuat seperti detergen, sehingga mampu membantu menurunkan tegangan permukaan yang terjadi antar sel. Senyawa saponin yang sudah diabsorbsi pada permukaan sel akan menyebabkan kerusakan dengan adanya peningkatan permeabilitas pada membran, sehingga bahan-bahan esensial tersebut yang dibutuhkan oleh bakteri untuk hidup menjadi hilang dan dapat menyebabkan kematian pada sel. ${ }^{9}$

Pasta gigi non-herbal juga mampu menurunkan skor plak dalam penggunaanya selama 14 hari, penurunan ini terjadi karena pada pasta gigi non-herbal terdapat kandungan surfectant atau deterjen, yang mempunyai fungsi sebagai antibakteri dan 
menurunkan tegangan pada permukaan gigi. Bahan tersebut bekerja dengan cara menurunkan tegangan pada permukaan dan melonggarkan ikatan debris yang menempel pada permukaan gigi sehingga pada saat adanya upaya mekanik yang diberikan terhadap permukaan gigi yang terdapat plak maka akan sangat membantu untuk eleminasi plak tersebut. ${ }^{10}$ Kandungan lain pada pasta gigi non-herbal yaitu adanya bahan yang bersifat abrasif. Bahan abrasif mampu membantu meningkatkan daya eliminasi terhadap plak sehingga plak yang menempel pada permukaan gigi dapat tereleminasi. ${ }^{3}$

Penelitian ini sesuai dengan penelitian yang dilakukan oleh Yendriwati bahwa kandungan yang terdapat dalam tumbuhan daun sirih diketahui memiliki efek antibakteri dalam rongga mulut yaitu mempengaruhi pertumbuhan streptococcus mutans. ${ }^{11}$ Penelitian lain juga menyatakan bahwa saponin dalam daun sirih yang diabsorbsi pada permukaan sel bakteri akan menyebabkan kerusakan dengan adanya peningkatan permeabilitas pada membran, sehingga bahan-bahan esensial yang dibutuhkan oleh bakteri untuk hidup menjadi hilang dan dapat menyebabkan kematian pada sel bakteri. ${ }^{9}$

Pada penelitian ini kedua pasta gigi mampu menurunkan skor plak dengan selisih penurunan skor plak adalah 4,29. Banyak faktor yang dapat mempengaruhi sehingga selisih dari penurunan skor plak dari kedua pasta gigi ini tidak terlalu jauh kemungkinan karena komunikasi antara peneliti dengan siswa, penyampaian dental health education (DHE) dan tehnik sikat gigi yang kurang dipahami siswa. Penyuluhan kesehatan gigi dan mulut merupakan suatu upaya yang dilakukan untuk merubah perilaku seseorang, sekelompok orang atau masyarakat sehingga mempunyai kemampuan dan kebiasaan untuk berperilaku hidup sehat di bidang kesehatan gigi dan mulut. Komunikasi yang ada antara anak dengan orangtua dan cara menyikat gigi sesuai teknik yang telah diajarkan kemungkinan mempengaruhi dari hasil penurunan plak pada gigi anak. Informasi yang disampaikan kepada anak kemudian disampaikan kepada orangtua adalah salah satu jenis komunikasi antar personal. Komunikasi tersebut memungkinkan orangtua ikut serta memberikan perhatian kepada anak sehingga secara tidak langsung orangtua ikut melakukan kontrol terhadap upaya kesehatan gigi dan mulut anak. ${ }^{12}$

Guru cenderung mempunyai pengaruh yang hampir sama dengan orangtua, sehingga komunikasi antara guru dan siswa juga berpengaruh terhadap upaya peningkatan kesehatan gigi dan mulut anak terutama dalam lingkup wilayah sekolah. ${ }^{13}$ Menjaga kesehatan gigi dan mulut pada anak usia sekolah bukan hanya menjadi tangung jawab dari petugas kesehatan, namun juga peran orangtua dan guru. Menurut Green dan Kreuler, komunikasi yang terjadi antara guru 
dan orangtua murid mempunyai pengaruh terhadap perilaku pada anak termasuk dalam perilaku menjaga kesehatan gigi dan mulut. Pengaruh tersebut dapat menimbulkan pola fikir terhadap anak sehingga anak akan berusaha menjaga kesehatan gigi dan mulutnya sendiri - sendiri. ${ }^{14}$

DHE merupakan suatu proses pendidikan yang timbul atas dasar kebutuhan kesehatan gigi dan mulut yang bertujuan untuk menghasilkan kesehatan gigi dan mulut yang baik dan dapat meningkatkan taraf hidup. Dalam proses pendidikan dan pengajaran, individu memperoleh pengalaman atau pengetahuan melalui berbagai macam alat bantu pendidikan yang diberikan. Masingmasing alat bantu mempunyai intensitas yang berbeda - beda dalam membantu persepsi seseorang. ${ }^{14}$

Faktor lain yang memberikan pengaruh pada penerimaan informasi oleh anak adalah kemampuan kognitif anak. Menurut Piaget (1950), anak usia SD mengalami tahap ketiga dan keempat perkembangan kognitif anak, yaitu tahap konkret operasional (umur 7-11 tahun) dan tahap formal operasional (umur 11-12 tahun). Pada kedua fase tersebut, anak sudah mampu berpikir dan memahami secara sistematis atas sesuatu sebagaimana kenyataannya contohnya mampu mengolah gambar, angka, serta konsep secara objektif. Dengan demikian, pada umur 8-12 tahun, anak sudah mampu menggabungkan sejumlah informasi secara sistematis, menggunakan rasio dan logika, memahami, dan membuat perkiraan di masa depan.

Adanya faktor kognitif dari dalam diri anak serta optimalisasi komunikasi yang diberikan serta adanya keikutsertaan orangtua dapat membantu penurunan plak pada anak. Demikian juga pada penelitian ini dimana di sampel berusia $8-12$ tahun yaitu yang sedang berada pada tahap konkret operasional dan tahap formal operasional sehingga anak usia tersebut sudah mampu memahami informasi yang sudah di sampikan kemudian mampu menerapkannya. ${ }^{15}$

\section{KESIMPULAN}

Berdasarkan hasil penelitian dan
analisis data mengenai perbedaan penggunaan pasta gigi herbal dan non-herbal terhadap penurunan indeks plak pada siswa SDN 2 Dinoyo Malang usia 8-12 tahun, dapat disimpulkan bahwa pasta gigi herbal lebih efektif dari pasta gigi non-herbal dalam menurunkan indeks plak pada anak sekolah dasar.

\section{DAFTAR PUSTAKA}

1. Sondang P, Harmada T. Menuju Gigi Dan Mulut Sehat, Pencegahan Dan Pemeliharaan. Edisi 1. Medan: USU Press; 2008; p. 32.

2. Salmiah S. Gingivitis Pada anak (Gingivitis Kronis, Gingivitis Yang Dipengaruhi ObatObatan Dan Gingivitis Karena Kondisi 
Tertentu). [Artikel Imiah]. Fakultas Kedokteran Gigi Universitas Sumatera Utara, Medan. 2009.

3. Mutmainnah M. 2013. Pengaruh Pasta Gigi yang Mengandung Ekstrak Daun Sirih dalam Mengurangi Plak dan Gingivitis pada Gingivitis Marginalis Kronis. [Skripsi].

Fakultas Kedokteran Gigi Universitas Hasanudin, Makassar. 2013.

4. Triwahyuni E, Wikanastri M. Analisis Kadar Detergent Anionik Pada Sediaan Pasta Gigi Anak-Anak. Jurnal Kesehatan. 2009; 2(2): 1-5.

5. Cahyanti P. Penggunaan Pasta Gigi Herbal Daun Sirih Lebih Menurunkan Akumulasi Plak Gigi daripada Pasta Gigi Non Herbal Flouride Pada Siswa Kelas VIII SMPK 1 Harapan Denpasar. [Skripsi]. Fakultas Kedokteran Gigi Universitas Mahasaraswati, Denpasar. 2014.

6. Rahmah R, Rachmadi P, Widodo. Perbandingan Efektivitas Pasta Gigi Herbal Dengan Pasta Gigi Non Herbal Terhadap Penurunan Indeks Plak Pada Siswa Sdn Angsau 4 Pelaihari. Dentino Jurnal Kedokteran Gigi, 2014, Vol.2 (2): 120

7. Ardianti G. Efektivitas Ekstrak Daun Sirih Sebagai Obat Kumur Terhadap Penurunan Plak Indeks (Studi Di Wilayah Kerja Puskesmas Kaliori Rembang). [Tesis]. Fakultas Ilmu Keolahragaan. Universitas Negeri Semarang, Semarang. 2011.
8. Ningsih Q, Lestari PE, Sulistyani E. Daya Hambat Ekstrak Daun Sirih Merah (Piper crocatum) terhadap Streptococcus mutans. [Repository]. Universitas Jember. 2013.

9. Moerfiah, Fira DSS. Pengaruh ekstrak daun sirih merah (piper cf. fragile benth) terhadap bakteri penyebab sakit gigi. Ekologia. 2011; 11: 30-5.

10. Hartono, SWA. Peran Kebersihan Rongga Mulut pada Pencegahan Karies dan Penyakit Periodontal. Maj. Ked. Gigi. (Dent. J.). 2001; 34(3a): 643-8.

11. Yendriwati H. Efek antibakteri sediaan daun sirih (piper betle I), obat kumur minyak essensial dan povidone iodine $1 \%$ terhadap streptococcus mutans. Dentika Dental Jurnal. 2008; 13(2): 145-8.

12. Liliweri A. Dasar-dasar komunikasi kesehatan. Yogyakarta: Pustaka Pelajar; 2007; p.2-22.

13. Astoeti TE. Total Quality Management dalam pendidikan kesehatan gigi di sekolah. Jakarta: PT Raja Grafindo Persada; 2006;p. 20-30.

14. Hutabarat N. Peran Petugas Kesehatan, Guru Dan Orantua Dalam Pelaksanaan Ukgs Dengan Tindakan Pemeliharaan Kesehatan Gigi Dan Mulut Murid Sekolah Dasar Di Medan Tahun 2009. [Tesis]. Sekolah Pasca Sarjana. Universitas Sumatera Utara, Medan. 2009. 